\title{
BLOOD $\mathrm{pH}$ AND CATION LEVELS IN RELATION TO EGG-SHELL FORMATION
}

\author{
R.-D. HODGES \\ Department of Poultry Research, Wye College \\ (University of London) near Ashford, Kent (Great Britain)
}

INTRODUC'TION

The fina1 processes of egg formation, the deposition of the albumen and shel around the yolk, take place while the egg is passing down the oviduct. Normally the time taken between the ovulation of the yolk and the oviposition of the finished egg is about 26 hours and during the greater portion of this time, approximately 20 hours, the egg remains in the shell gland. Two basic processes are carried out whilst the egg is in the shell gland : firstly, the greater part of the plumping of the albumen and secondly, the formation of the shell. These two processes require considerable quantities of ions, particularly the calcium which as calcium carbonate forms about $95 \mathrm{p}$. Ioo of the shell, but also other ions involved in the plumping process such as potassium and sodium. As the shell gland has little or no capacity for the storage of these substances, most of the ions which are incorporated into the egg have to be derived from the shell gland blood supply when the gland is active. The only exceptions to this are the bicarbonate ions which go to form the shell carbonate and these are almost certainly derived mainly from the shell gland metabolic carbon dioxide (HODGES and LÖRCHER, I967).

The purpose of the present series of experiments was to obtain a comprehensive picture of the fluctuations of several of the more important ions associated with plumping and shell formation both in systemic and shell gland blood and during the whole of the shell formation cycle. Although a number of investigations of this nature have been performed in the past, most of them only measured calcium levels and this only on systemic blood (Charles and Hogben, I933; Polin and Sturkie, I957; WINGET and SMith, I958; HeRTELENDY and TAYLOR, I96I). If shell gland blood also was sampled it was done only on a very limited scale (KNOWLES, HART and HALPIN, I935; Wingert, SMith and Hoover, I958; Hunsaker and Sturkie, I96r). In this series the cations calcium, potassium and sodium have been measured and at the same time, in order to obtain a measure of the blood acid-base fluctuations which occur during shell formation, the blood $\mathrm{pH}$ was determined. 


\section{MATERIALS AND METHODS}

The birds used in the experiments were actively-laying hybrid hens of the White Leghorn strain (Sterling White Links and Shaver 288's). Each bird was anasthetized with sodium pentabarbitone and ether and a plastic cannula was inserted into the posterior end of the inferior oviducal vein (HodGes, 1965) using the technique described by HoDGEs (1966). Cannulae were also inserted into the sciatic artery and vein in the upper left leg. From these three cannulae it was possible to take samples of systemic arterial and venous blood and of shell gland venous blood. Since the main artery supplying the shell gland, the hypogastric artery, branches off from the femoral artery at the level of the left kidney (F REEDMAN and STURKIE, I963) the blood being sampled from the sciatic artery was of similar composition to that entering the shell glancl.

After the operation the birds were kept lightly anasthetized with ether and were heparinized. Hourly blood samples were taken throughout the period of each experiment and the timing of sampling to coincide with regular hourly periods within the shell formation cycle was performed by timing the laying of the previous egg or by the oviposition or the entry of an egg into the shell gland cluring the experimental period. Blood samples for $\mathrm{pH}$ determination were taken into capillary tubes $(80 \mu \mathrm{l})$ and the $\mathrm{pH}$ values were measured with a Radiometer $\mathrm{pH}$ Micro-Electrode and $\mathrm{pH}$-Neter 27. At the same time samples of $0.75 \mathrm{ml}$ were taken into centrifuge tubes and the plasma was used for the cation measurements. Plasma sodium and potassium were measured with an EEL flame photometer (Wooton, I964) using $0.2 \mathrm{ml}$ of plasma and plasma calcium was measured by means of Trinder's method (Trinder, I960) using 0.1 ml of plasma.

The experimental series was controlled by using unancsthetized, unrestrained birds. Cannulae were inserted into the wing veins of six birds and samples were taken every two hours over a period of approximately 24 hours.

The time scale of the tables is divided into two parts. Firstly, there is the period of shell gland quiescence between the point of lay (Egg Laid) and the time when another egg entered the shell gland (Egg Entered Shell Gland). Secondly, there is the period of shell formation lasting for 2o hours.

\section{RESULTS}

$$
p H \text {. (Control values - table I; experimental values - table } 2 \text { ) }
$$

The control $\mathrm{pH}$ values were rather variable, but did show a regular fluctuation throughout the shell formation period, with a maximum level of about 7.38 at six hours after the egg entered the shell gland and a minimum value of 7.32 at 16 hours of shell formation. This pattern was somewhat obscured by a secondary fall in $\mathrm{pH}$ which occurred between four and six hours after lay.

In the experimental birds the pattern of the arterial results was basically similar to that of the controls, a maximum of $7.5 \mathrm{I}$ two hours after the egg entered the shell gland and a minimum of 7.43 at thirteen hours of shell formation, but these points occurred about three hours earlier in the experimental birds than in the controls.

The shell gland venous values, in general, closely followed the pattern of the arterial values at a rather more acid level. However, whereas this arterio-venous difference was minimal during the period of shell gland quiescence (0.015 pH units four hours after lay), during the following period of shell formation the difference gradually increased to reach a maximum of $0.079 \mathrm{pH}$ units at the fifteenth hour of shell formation (table 3). From then on the arterio-venous difference decreased until the egg was laid. 
TABLE I

Wing vein blood $p H$ and plasma total calcium values from the control birds. Samples taken at 2-hourly intervals throughout the shell formation cycle

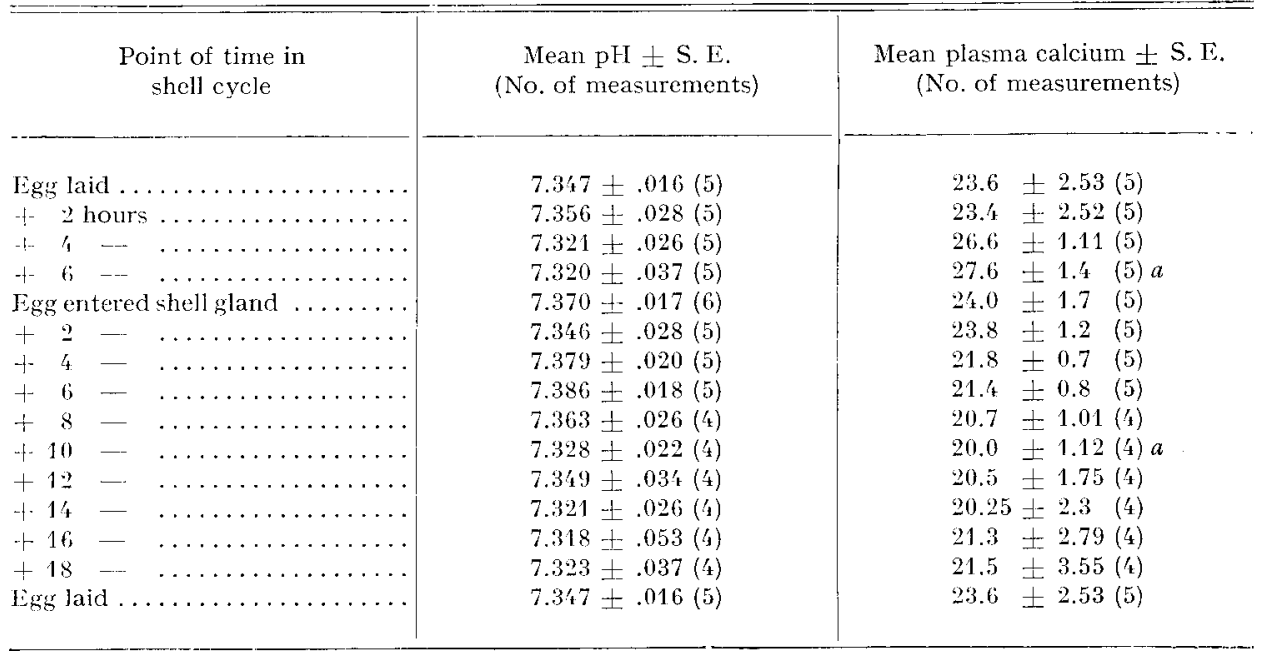

a. These values are not significantly different $(\mathrm{P}>0.05)$.

Calcium. (Control values - table I; experimental values - table 4)

The fluctuations in plasma total calcium which were found in the control birds appeared to be closely associated with shell formation. A maximum level of $27.6 \mathrm{mg}$ p. Ioo occurred at six hours after lay and a minimum level of approximately $20.2 \mathrm{mg}$ p. Ioo occurred between the tenth to fourteenth hours of the next shell formation period. The difference of $7.2 \mathrm{mg}$ p. Ioo between these maximum and minimum points was not, however, significant $(\mathrm{P}>0.05)$.

In the experimental birds the sciatic arterial and venous values were very similar to each other throughout the whole of the experimental period. Cyclical fluctuations were again found during the shell formation period but they were not identical to those found in the controls. Maximum levels of $20.3 \mathrm{mg}$ p. Ioo occurred at oviposition and again during the first hour of the shell formation period, and the minimum level of $16.2 \mathrm{mg} \mathrm{p}$. Ioo occurred at ten hours of shell formation. The difference of $4.5 \mathrm{mg}$ p. Ioo between the maximum and minimum points was not significant $(\mathrm{P}>0.05)$. During the second half of the shell formation period the plasma calcium level slowly recovered. It was noticeable that the experimental birds had an average systemic plasma calcium level at least $3 \mathrm{mg} \mathrm{p}$. Ioo below that of the controls.

The arterio-shell gland venous differences were very small during the first six hours of the shell gland quiescent period (average difference $=0.2 \mathrm{Img} \mathrm{p}$. Ioo). Between the sixth hour of quiescence and the second hour of shell formation this difference had increased slightly (average difference $=0.85 \mathrm{mg} \mathrm{p}$. Ioo) and by the third 


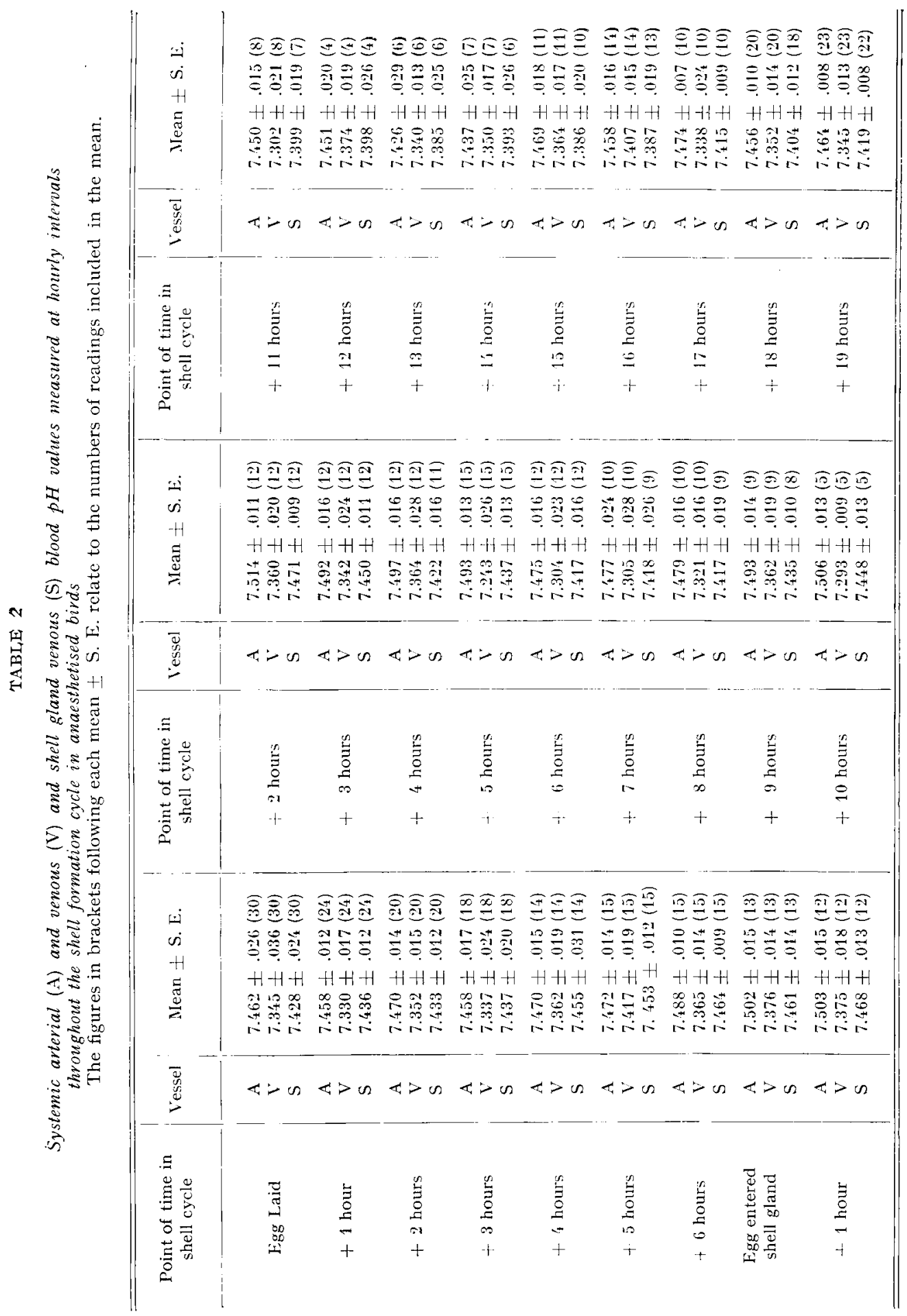


hour of shell formation a considerable difference had developed. At the fifth hour a statistically significant difference $(P<0.05)$ of $3.9 \mathrm{mg}$ p. Ioo was apparent and thereafter an arterio-venous difference of this magnitude ( 2 to $4 \mathrm{mg}$ p. roo) was maintained until the sixteenth hour of shell formation. Between this latter point and the time of lay the difference gradually decreased.

TABLE 3

Systemic arterial-shell gland venous differences in blood $p H$. Mean values from the data in Table 2

\begin{tabular}{|c|c|c|c|}
\hline $\begin{array}{l}\text { Point of time } \\
\text { in shell cycle }\end{array}$ & $\begin{array}{c}\text { Mean A-S difference } \\
\text { (No. of values) }\end{array}$ & $\begin{array}{l}\text { Point of time } \\
\text { in shell cycle }\end{array}$ & $\begin{array}{c}\text { Mean A-S difference } \\
\text { (No. of values) }\end{array}$ \\
\hline 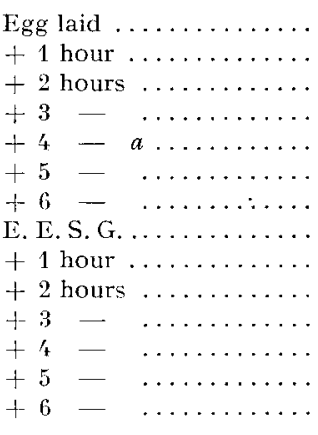 & $\begin{array}{l}0.034 \pm .008(30) \\
0.021 \pm .007(24) \\
0.037 \pm .009(20) \\
0.021 \pm .008(18) \\
0.015 \pm .007(13) \\
0.019 \pm .007(15) \\
0.024 \pm .005(15) \\
0.030 \pm .008(13) \\
0.035 \pm .007(12) \\
0.043 \pm .006(12) \\
0.042 \pm .009(12) \\
0.064 \pm .013(11) \\
0.056 \pm .006(15) \\
0.058 \pm .007(12)\end{array}$ & $\begin{array}{l}+7 \text { hours } \\
+8- \\
+9- \\
+10- \\
+11- \\
+12- \\
+13- \\
+14- \\
+15-a \\
+16- \\
+17- \\
+18- \\
+19- \\
\text { Egg laid }\end{array}$ & $\begin{array}{l}0.063 \pm .005(9) \\
0.064 \pm .007(9) \\
0.051 \pm .004(8) \\
0.066 \pm .007(5) \\
0.048 \pm .007(7) \\
0.053 \pm .009(4) \\
.0 .061 \pm .017(6) \\
0.036 \pm .010(6) \\
0.079 \pm .008(10) \\
0.071 \pm .009(13) \\
0.060 \pm .008(10) \\
0.047 \pm .006(18) \\
0.042 \pm .006(22) \\
0.034 \pm .008(30)\end{array}$ \\
\hline
\end{tabular}

a. Values are significantly different at the $1 \%$ level $(\mathrm{P}<0.01)$.

Potassium. (Control values - table 5 ; experimental values - table 6)

In both the control and experimental birds a cyclical fluctuation of plasma potasium values was found to occur in association with the shell formation cycle. In the controls the maximum level (I7.I $\mathrm{mg}$ p. IOo) occurred six hours after the previous egg was laid and the minimum value of Ir. $6 \mathrm{mg}$ p. Ioo was found at the tenth hour of shell formation. Between this latter point and the point of lay it recovered to I4.5 $\mathrm{mg}$ p. I0o. The difference of $5.5 \mathrm{mg}$ p.. Ioo between the maximum and minimum points was statistically significant $(P<0.05)$.

In the experimental birds maximum potassium levels occurred during the quiescent period ( $77 \mathrm{mg}$ p. IOO) and minimum values between the fourth and eighth hours of shell formation ( $12 \mathrm{mg}$ p. IOO). The difference of $4.5 \mathrm{mg} \mathrm{p}$. Ioo between the combined arterial and shell gland venous figures at four hours after lay and at eight hours of shell formation was statistically significant $(P<0.05)$. The minimum values in the experimental birds occurred somewhat earlier than in the controls. It was evident at nearly every point throughout the experimental cycle that the systemic venous potassium values were greater than the systemic arterial values (average difference $0.8 \mathrm{mg} \mathrm{p}$. IOO; greatest difference $1.9 \mathrm{mg}$ p. roo). These differences were 


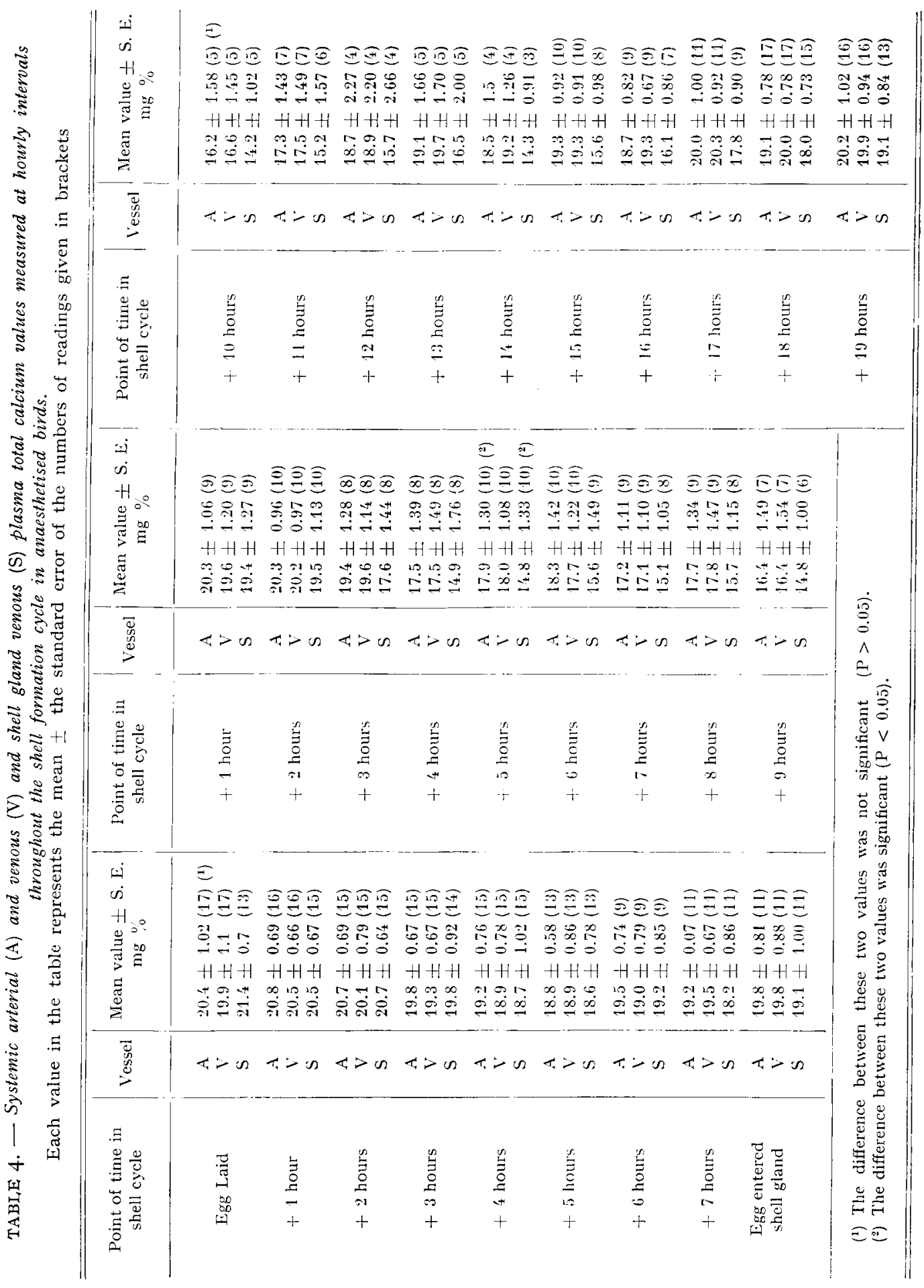


TABLE 5

Wing vein plasma potassium and plasma sodium values from the control birds. Samples taken at 2-hourly intervals throughout the shell formation cycle.

\begin{tabular}{|c|c|c|}
\hline $\begin{array}{l}\text { Point of time in } \\
\text { shell cycle }\end{array}$ & $\begin{array}{c}\text { Mean plasma potassium } \pm \mathrm{S} . \mathrm{E} . \\
\text { (No. of measurements) } \\
\text { mg } \%\end{array}$ & $\begin{array}{c}\text { Mean plasma sodium } \pm \text { S. E. } \\
\text { (No. of measurements) } \\
\text { mg } \%\end{array}$ \\
\hline Egg laid & $14.5 \pm 0.90(5)$ & $312=10.4(5)$ \\
\hline+2 hours ... & $15.5 \pm 0.98(5)$ & $323 \pm 13.4(5)$ \\
\hline$-+\div-\ldots$ & $16.3 \pm 0.89(5)$ & $314 \pm 9.0(5)$ \\
\hline$\ldots \ldots \ldots \ldots$ & $17.1 \pm 1.17(5) a$ & 30.3 士 $8.7(5) b$ \\
\hline Egg entered shell gland ...... & $15.7 \pm 0.77(6)$ & $311 \pm 7.1(6)$ \\
\hline+2 hours $\ldots \ldots \ldots \ldots \ldots$ & $16.2 \pm 1.28(5)$ & $308 \pm 11_{4}^{\prime} .0(5)$ \\
\hline$\dashv \quad ;-\ldots \ldots \ldots \ldots \ldots$ & $13.9 \pm 1.48(5)$ & $3018 \pm 11.4(5)$ \\
\hline$+6-\ldots \ldots \ldots \ldots \ldots \ldots$ & $12.9 \pm 1.05(5)$ & $304 \pm 22.5(5)$ \\
\hline$+8-\ldots \ldots \ldots \ldots \ldots \ldots$ & $.12 .6 \pm 0.50(4)$ & $30 \% \pm 15.7(4)$ \\
\hline$+10-\ldots \ldots \ldots \ldots \ldots \ldots$ & $11.6 \pm 0.60(1) a$ & $304 \pm 19.6(4)$ \\
\hline$+12-$ & $12.9 \pm 1.98(1)$ & $309 \pm 15.8(t)$ \\
\hline$+1:-$ & $12.0 \pm 0.97(4)$ & $309 \pm 23.2(4)$ \\
\hline$\ldots \ldots \ldots \ldots \ldots$ & $13.1 \pm 1.2 \%(4)$ & $326 \pm 5.6(1)$ \\
\hline$+18-\ldots$ & $14.2 \pm 0.89(1)$ & $326 \pm 7.4(4) b$ \\
\hline Egg laid $\ldots \ldots \ldots \ldots \ldots \ldots \ldots$ & $14.5 \pm 0.90(5)$ & $312 \pm 10.4(5)$ \\
\hline
\end{tabular}

a. Values are significantly different at the 5 p. 100 level $(\mathrm{P}<0.05)$.

$b$. These values are not significantly different $(P>0.05)$.

greatest during the first fourteen hours of shell formation. On the other hand no definite and consistently positive arterio-shell gland venous differences were found within the period of shell formation except during the last three hours, when differences of I.O to $2 . I \mathrm{mg} \mathrm{p}$. Ioo were measured.

\section{Sodium. (Control values - table 5 ; experimental values - table 7)}

In the control birds the plasma sodium levels remained fairly constant and no significant fluctuations were measured at any point during the shell formation cycle. Similarly in the experimental birds no overall pattern of fuctuations could be detected and no consistent arterio-shell gland venous differences were demonstrated.

There was, however, one anomaly between the control and experimental birds ; the values for the former were approximately $40 \mathrm{mg}$. Ioo lower than those for the latter throughout the whole of the cycle.

\section{DISCUSSION}

\section{$p H$}

The control results were only partially in agreement with those of MoNGIN and LACASSAGNE ( 1964 ), who also sampled wing vein blood. Their $\mathrm{pH}$ values were maximal when the egg entered the shell gland and were minimal at $I 7$ hours of shell formation. 


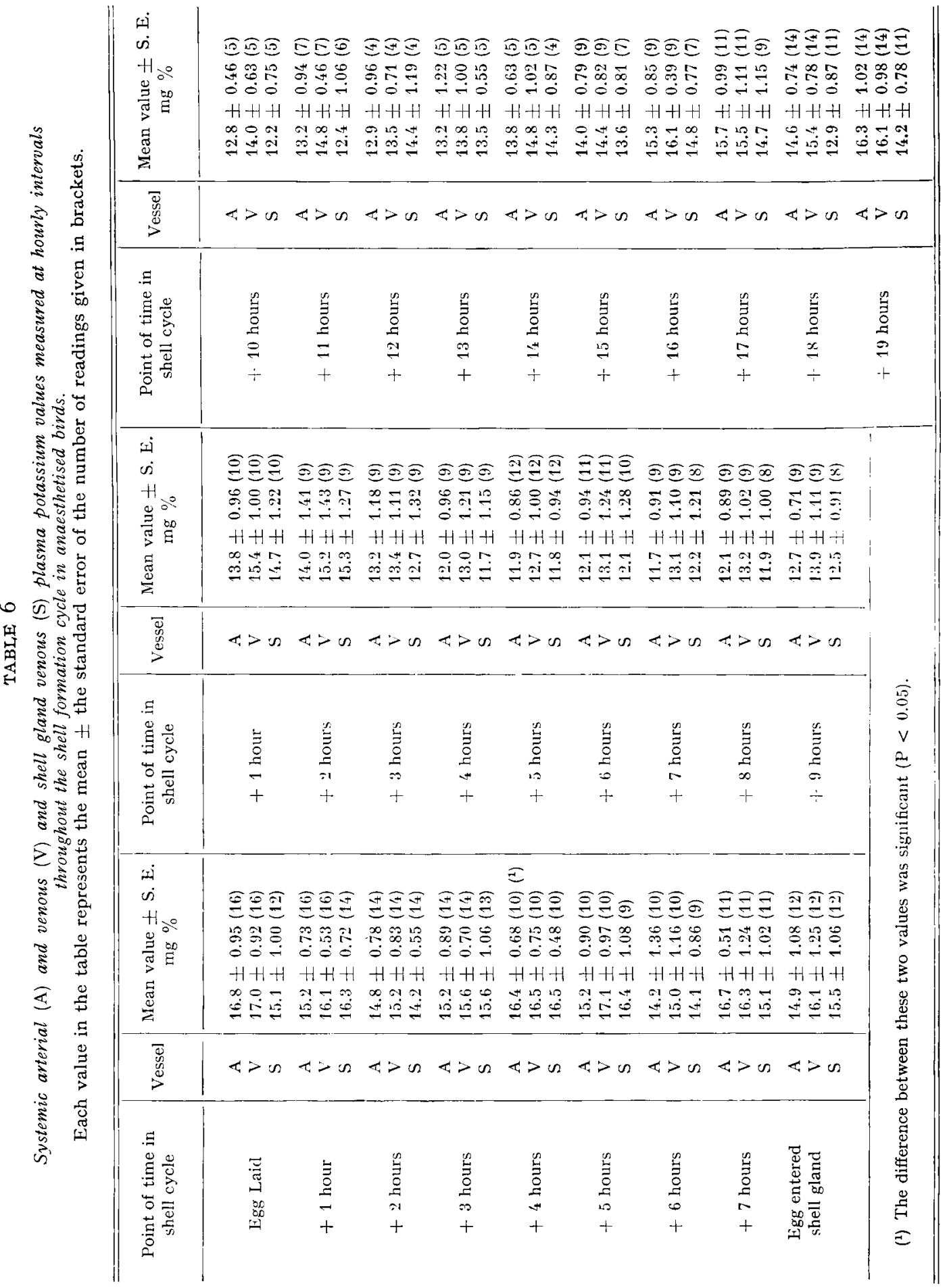




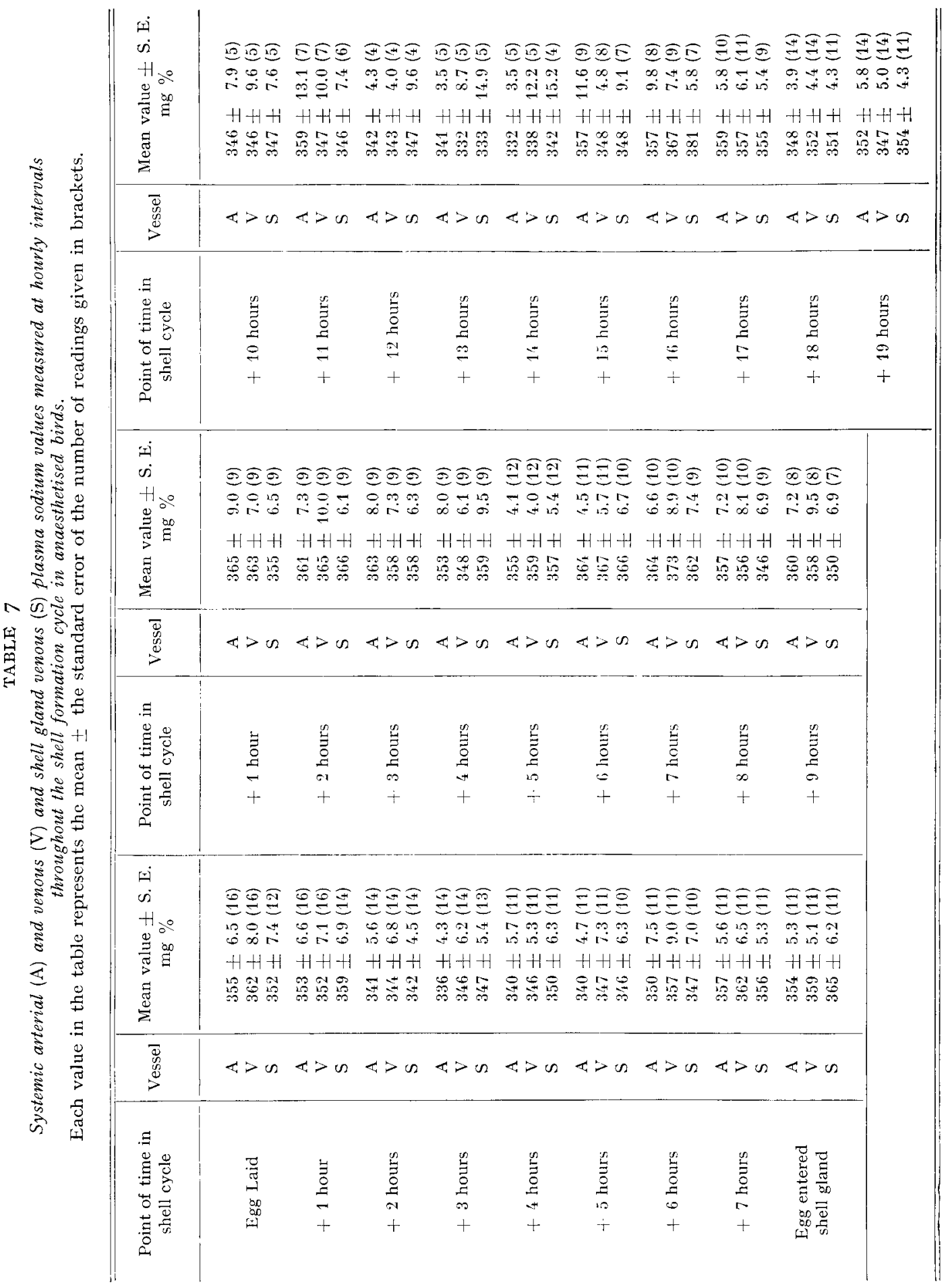


The present results were overall at least o.oI $\mathrm{pH}$ units lower than those of MongIN and LACASSAGNE and, in the case of the maximum point, approximately 5 hours later in the shell formation cycle. However, it was not easy to relate their time scale to the present one. Another point of difference was that whereas during the shell gland quiescent period the present results were in the process of recovering from the minimal values which had occurred before the oviposition of the previous egg, MoNGIN and LACASSAGNE's results were constant and maximal.

In discussing the experimental results it is necessary to acknowledge that the $\mathrm{pH}$ values would be adversely affected by the anaesthetic. Although the average arterial $\mathrm{pH}$ in these experiments (7.474) was slightly higher than that found for unanaesthetised birds of a similar strain (7.4I0), and thus respiratory depression due to the anaesthetic would not seem to have occured, other experiments have shown that birds with a similar arterial $\mathrm{pH}$ may have an unusually high $\mathrm{pCO}_{2}$ and bicarbonate, showing that some respiratory disturbance had occured. This was minimised by keeping the birds only lightly anaesthetised after the actual operation.

The sciatic venous values were very irregular and did not follow the trends occurring in the sciatic arterial and wing vein blood. This may have been due to the fact that the venous cannulae were inserted well into the vein, thus drawing off blood from the region of the junction of the sciatic vein with the renal portal vein. It is possible that blood from the renal portal vein is not truly representative of systemic venous blood.

The arterial and shell gland venous results possessed maximum and minimum values which coincided closely with those of Mongin and LACAssagne (I964), but the actual cyclical pattern of these results corresponded more closely with the present controls than with the values of MONGIN and LACASSAGNE. After oviposition $\mathrm{pH}$ values slowly increased to a maximum just after the next egg entered the shell gland and, as the next phase of shell formation was initiated, the $\mathrm{pH}$ gradually declined to the minimum at I3 hours of shell formation. Thereafter it recovered to about midway between minimum and maximum points at the time of lay.

Although the shell gland venous $\mathrm{pH}$ values in general followed the trends of the arterial values, the arterio-venous $\mathrm{pH}$ difference varied according to the phase of shell formation and thus appears to be closely associated with the process of egg shell formation. The difference was minimal during quiescence and at the beginning of shell formation, but steadily increased from then on until the fifteenth hour of shell formation (there was some irregularity in the results between 9 and I4 hours). After the fifteenth hour the difference decreased rapidly until the point of lay, indicating that the rate of shell formation may be decreasing during this period.

It was originally considered that the egg shell carbonate was derived from bicarbonate ions removed from the blood stream by the shell gland (GuTowsra and Mi'TCHEIL, I945), and the removal of such bicarbonate ions could account for changes in the $\mathrm{pH}$ of the shell gland venous blood. GUTOWSKA and MrTCHELL's theory received support from the fluctuations of systemic bicarbonate found by MONGIX and LACASSAGNe (I964). More recently, however, HodGEs and LöRcher (I967) have demonstrated that the egg shell carbonate is derived from the metabolic carbon dioxide of the shell gland and that during this process considerable amounts of hydrogen ions are produced. The development of the large A-V. difference would therefore appear to be mainly associated with the production of hydrogen ions by the shell gland and 
the changes that occur in the systemic $\mathrm{pH}, \mathrm{pCO}_{2}$ and bicarbonate levels concurrently with this $\mathrm{A}-\mathrm{V}$. difference would appear to be due to the introduction of large amounts of hydrogen ions into the circulation and to the compensatory efforts of the birds regulatory mechanisms. In the present experimental data the systemic pH began a gradual recovery after the thirteenth hour of shell formation even though the process of shell formation was still actively occurring, thus indicating the initiation of a compensatory mechanism. From the data of Mongin and LACASSAGNE (Ig64) it can be seen that a slight respiratory alkalosis develops during shell formation as a partial compensation for the increasing metabolic acidosis. However, this acidosis develops steadily until about $\mathrm{I} 7$ hours of shell formation (three hours before lay), and then the process is reversed along the line of a metabolic alkalosis indicating active compensation by the kidneys. On the other hand, ANDERSOx ( 1967 ) has shown, by measuring the $\mathrm{pH}$ of the urine, that secretion of acid by the kidneys begins soon after the initiation of active shell formation (I5-I6 hours before the egg is laid), indicating that compensation by the kidneys has begun long before the reversal of the metabolic acidosis. This suggests that by $I 7$ hours of shell formation shell secretion is decreasing and that the kidney, which before was unable to compensate for the production of hydrogen ions, can now reverse the metabolic acidosis. However, in the present data the reversal apparently began earlier, at the thirteenth hour of shell formation, suggesting that the kidneys of these birds were able to reverse the metabolic acidosis at an earlier stage. Without further acid-base data this interpretation can only be a suggestion.

\section{Calcium}

The plasma calcium results are in general agreement with previous work. WINGET and SMITH (I958) demonstrated similar fluctuations in total plasma calcium during the shell formation cycle and HERTELENDY and TAYLOR (I96I) showed a similar overall drop in plasma calcium between shell gland quiescence and the period of active shell formation. However, the drop in systemic plasma calcium which was found in both the control and experimental birds in the present experiments was not found to be statistically significant. This may have been due to the very large variation that can occur between birds (HERTELENDY and TAYLOR, I96I).

This fall in systemic plasma calcium, in the present experimental birds, continued until the tenth hour of shell formation. Thereafter the trend was reversed and levels returned to normal just after oviposition, in spite of the fact that shell calcification appeared to continue at a steady rate across most of the period of shell formation. This reversal in the fall of plasma calcium may be associated with a rapid mobilisation of calcium from the medullary bone. FUSSEL (Ig66) has demonstrated that there is frequently a considerable increase in urinary phosphorus output during the last eight or ten hours of shell formation, indicating a rapid breakdown of bone mineral. The autoradiographic studies of TYIER (I954) have also shown that the calcium laid down during the last few hours of shell formation is mainly of skeletal origin. In the present series not all of the birds were early layers and thus the whole of the rise in plasma calcium cannot be ascribed to bone mobilisation; part of this rise, at least during the last four or five hours before lay, must be attributed to renewed absorption of calcium from the intestine.

The present data is also in general agreement with previous work on the rates 
of calcification of the egg shell. The work of BURMESTER, SCOTT and CARD (I939), BURMESTER (I940) and BRADFIELD (I95I) have indicated that during the first four hours that the egg spends in the shell gland the rate of calcification gradually increases and thereafter a rapid and constant rate of calcification occurs throughout the remaining sixteen hours before lay. In the present results a large arterio-venous difference had developed by the fourth hour after entry into the shell gland, and this continued for about twelve hours. However, after the sixteenth to seventeenth hours the difference rapidly decreased, indicating a gradual decrease in the rate of shell formation.

\section{Potassinm}

Similar patterns of fluctuation were found in both the potassium and calcium levels even though potassium mobilisation is mainly related to plumping and calcium movement is related to shell formation. The process of plumping begins in the isthmus and whilst it and shell formation are progressing the potassium content of the albumen is approximately doubled (DRAPER, I 966). Accumulation of this ion even continues when a hard shell is formed over the entire surface (DrAPER, Ig66). It can be seen from table 8 that the initial fall in plasma potassium approximately coincided with the beginning of the rapid uptake of potassium into the albumen. The reciprocal relationship between plasma and albumen potassium continued until about the tenth hour of shell formation. From then on, however, the trend in plasma potassium was reversed although there was no cessation of increase of albumen potassium.

\section{TABLE 8}

Comparison of potassium levels in blood plasma (wing vein), shell gland fluid and egg albumen during plumping and shell formation

Egg albumen figures recalculated from DRAPER (I966) and the shell gland fluid figures recalculated from EL JACK and LAKE (I967)

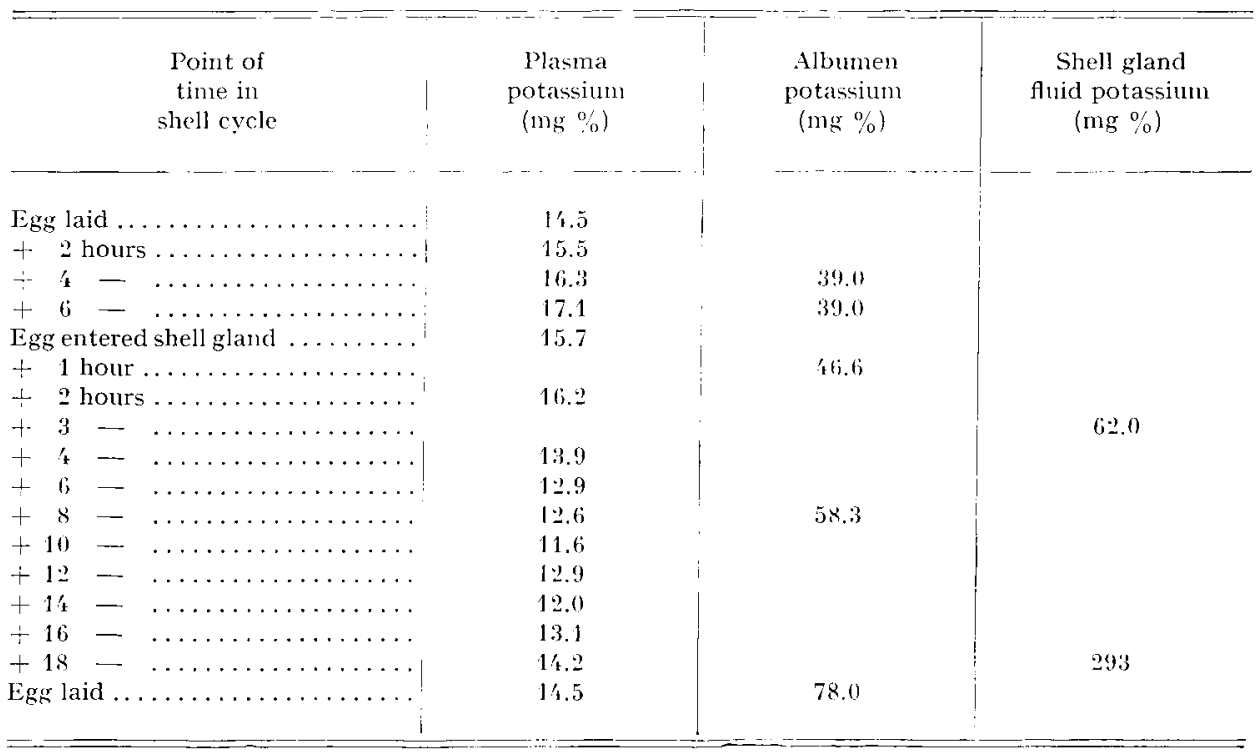


No arterio-shell gland venous potassium differences were found throughout almost the whole of the plumping/shell formation period and this was to be expected as, on the basis of the amount of potassium transferred into the albumen over the period of twenty hours, a rough calculation only gives an average $A-V$. difference of $0.2 \mathrm{mg} \mathrm{p}$. IOo, which would not become evident in the results. However, a difference of about I-2 mg p. Ioo was measured during the last three hours of shell formation. This can probably be explained by some results of EI, JAcK and LAKE (I967) (table 8). They measured the ionic constituents of the shell gland fluid at two points, during plumping and shortly before the egg was laid. They found that the potassium level of plumping fluid was only $\mathrm{I} 6 \mathrm{mmol} / 1$. whilst that taken towards the end of shell formation was $75 \mathrm{mmol} / 1$. If such an unusually high potassium level could be shown to occur only during the last three hours of shell formation, then this would account for the arterio-venous difference during this period.

\section{Sodium}

Whilst plumping is occurring the total amount of sodium in the albumen increases by 50 p. IOO, from approximately I Io mmol. to approximately I60 $\mathrm{mmol}$. (DRAPER, I966). However, owing to the very large uptake of water, the concentration in the albumen drops from $\mathrm{I} 27 \mathrm{mmol} / 1$. in the magnum to about $60 \mathrm{mmol} / 1$. when laid. These comparatively small amounts of sodium were apparently not large enough to show up as either an overall plasma variation or as an $\mathrm{A}-\mathrm{V}$. difference.

There was one rather anomalous factor present in the plasma sodium results. The control results were consistently about $40 \mathrm{mg}$ p. Ioo lower than the experimental results. There does not seem to be, at present, any satisfactory explanation for this.

In the cases of the $\mathrm{pH}$, the calcium and the potassium results it was noted that a maximum level was found at about the time of entry of an egg into the shell gland and a minimum level occurred at, or just after, the mid-point of the period of shell formation. In all three cases the levels returned gradually towards normal after the minimum point was passed and thus, although shell formation continued steadily for several more hours, the trend in all these three parameters was reversed. Because of this close similarity in time and trend it seemed possible that there was some common cause or factor underlying all three. This common factor may be the activity (excretory or resorbtive) of the kidney, but it will not be possible to demonstrate this until the complete pattern of excretion during shell formation is known.

\section{ACKNOWLEDGEMENTS}

The author wishes to express his thanks to Miss C. FreEman for technical assistance.

The Radiometer blood acid-base equipment was purchased with a grant from the Central Research Fund of the University of London. 


\section{SUMMARY}

I. Cannulations of the inferior oviducal vein, the sciatic artery and the sciatic vein were performed upon actively-laying, anaesthetised hens. A control series of unanasthetized birds were cannulated only in the wing vein. All cannulac were sampled at hourly intervals during the shell formation cycle and blood $\mathrm{pH}$, plasma total calcium, potassium and sodium were measured.

2. $\mathrm{pH}$. Arterial $\mathrm{pH}$ was at a maximum of $7.5 \mathrm{I}$ two hours after the egg entered the shell gland and at a minimum of 7.43 at thirtecn hours of shell formation. The shell gland venous blood in general followed the arterial trends at a more acid level but, cluring shell formation, an increasing $\mathrm{A}-\mathrm{T}$. difference developed, reaching a maximum of $0.079 \mathrm{pH}$ units at 5 hours of shell formation.

3. Calcium. Cyclical fluctuations of plasma total calcium were found with a maximum level (20 $\mathrm{mg}$ p. Ioo) during the quiescent period and a minimum level ( $16 \mathrm{mg} \mathrm{p}$. Ioo) at ro hours of shell formation. During shell formation an A-V. difference of $2-4 \mathrm{mg}$ p. roo developed.

4. Potassium. A cyclical pattern of plasma potassium associated with the shell formation cycle was again found. Maximum levels ( $17 \mathrm{mg}$ p. Ioo) occurred during the quiescent period and minimum values (r $2 \mathrm{mg} \mathrm{p}$. Ioo) at 4 to 8 hours of shell formation. An A-V. potassium difference ( $1-2 \mathrm{mg}$ p. IOO) was only found during the last three hours before lay.

5. Sodium. No cyclical pattern of sodium values or consistent $A-V$. differences were found which could be associated with the shell formation cycle.

6. The significance of the results was discussed in relation to the processes of plumping and shell formation.

\section{RÉSUMÉ}

\section{VARIATIONS DU PH ET DES CATIONS DU SANG \\ LORS DE LA FORMATION IDE LA COQUILLE DE I,'GUF CHEZ LA POULE}

I. Des canules ont été insérées dans l'artère et lá veine sciatique et dans la veine inféricure de l'oviducte de poules ancsthésiées. Des poules témoins non anesthésiées furent seulement canulées dans la veine alaire. Des prélèvements de sang ont été effectués chaque heure pendant la fortion de la coquille et le $\mathrm{pH}$ du sang ainsi que la teneur en calcium total, potassium et sodium du plasma ont été mesurés.

2. pH. Les valeurs artérielles présentent un maximum de $7,5^{\mathbf{I}}$ deux heures après l'entrée dans la glande coquillière et un minimum de 7,45 treize heures après le début de la formation de la coquille. Le sang veineux de la glande coquillière tend en général à suivre les valeurs artérielles à un niveau plus acide mais, pendant la formation de la coquille, une différence artério-veineuse croissante se développe qui atteint un maximum de 0,079 unités $\mathrm{pH}$ au stade $\mathbf{5}$ heures de formation de la coquille.

3. Calcium. La teneur en calcium total du plasma présente des variations cycliques, le niveau maximal (20 $\mathrm{mg}$ p. 100) intervenant pendant la période de repos de la glande coquillière et le niveau minimal (I $6 \mathrm{mg}$ p. Ioo) après Io heures de formation de la coquille. Au cours du dépôt de la coquille, une différence artério-veincuse de 2 à $4 \mathrm{mg}$ p. Ioo se développe au niveau de la glande coquillière.

4. Potassium. Il apparaît également des fluctuations cycliques de la kaliémie liées à la formation de la coquille. Les valeurs maximales ( $7 \mathrm{mg}$ p. Ioo) sont trouvées durant la période de repos et les valeurs minimales ( $12 \mathrm{mg} \mathrm{p}$. I oo) entre 4 ct 8 heures de formation de la coquille. Il n'existe aucune différence entre les teneurs des artères et des veines de la glande coquillère sauf pendant les trois dernières hcures précédant l'oviposition où un écart de $\mathrm{I}$ à $2 \mathrm{mg} \mathrm{p}$. Ioo est enregistré.

5. Sodium. Aucun comportement cyclique de la natrémie ni de différence artério-veineuse utérine ne sont trouvés qui puissent être associés au cycle de formation de la coquille.

6. La signification de ces résultats est discutée en rapport avec le " plumping " ct la formation de la coquille de l'ouf. 


\section{REFERENCES}

AndFrsox R. S., I967. Acid-base changes in the excreta of the laying hen. Vet. Rec., 80, 3I4-5.

Bradfield J. R. G., I95I. Radiographic studies on the formation of the hen's egg shell. $J$. Exp. Biol. 28, I $25-40$.

Burmester B. R., 1940. A study of the physical and chemical changes of the egg during its passage through the isthmus and uterus of the hen's oviduct. $J$. Exp. Zool., 84, 445-500.

Burmester B. R., Scott H. M., Card L. E., 19.39. Rate of egg shell formation in the hen. Proc. VIIth World's Poultry Science Congress, Cleveland, Ohio, pp. 99-ror.

Charles E., Hogben L., I933. The serum calcium and magnesium level in the ovarian cycle of the laying hen. Quart. J. Exp. Physiol., 23, 343-9.

Drapier M. H., I966. The transport of minerals to the white of the hen's egre. Proc. YIIIth Wonld's Poultry Science congress, Kiev, pp. 333-6.

EL JACK M. H., LAKE P. L., I967. The content of the principal inorganic ions and carbon dioxide in uterine fluids of the domestic hen. J. Reprod. Fertil,. 13, 127-32.

Freedman S. L., Sturkie P. D., ig63. Blood vessels of the chicken's uterus (shell gland). Amer. J. Anat., 113, I-7.

Fussel M. H., I966. Observations on the intestinal absorption and urinary excretion of calcium and phosphorus in the hen. Proc. XIIIth World's Poultry Science Congress, Kiev., pp. 309-I3.

Gutowska M. S., Mitchell C. A., I945. Carbonic anhydrase in the calcification of the egrg shell. Poultry Sci, 24, I59-67.

Hertelendy F., Thylor T. G., I96r. Changes in blood calcium associated with egg shell calcification in the domestic fowl. I. Changes in total calcium. Poultry Sci., 40, ro8-r4.

Hodges R. 1)., I965. The blood supply to the avian oviduct, with special reference to the shell gland. J. Anat., 99, $4^{85}-506$.

Hodges R. D., I966. Changes in blood $\mathrm{pO}_{2}$ and $\mathrm{pH}$ during the formation of the egg shell in laying hens. Proc. XIIIth World's Poultry Science Congress, Kiev, pp. 3I4-3Ig.

Hodges R. D., Lorcher K., r967. Possible sources of the carbonate fraction of egg shell calcium carbonate. Nature, 216, 609-Io.

Hunsaker W. G., Sturkie P. D., I96r. Removal of calcium from uterine blood during shell formation in the chicken. Poultry Sci., 40, $1348-52$.

Knowles H. R., Hart E. B., Halpin J. G., 1935. The variation in the calcium level of the blood of the domestic fowl. Poultry Sci., 14, 83-9.

Mongin P., Lacassagne L., rg64. The physiology of the formation of the shell of the hen's egg and the acid-base equilibrium of the blood (in French). C. R. Acad. Sci., Paris, 258, 3093-4.

Polin 1)., Sturkie P. D., I957. The influence of the parathyroid on blood calcium levels and shell deposition in laying hens. Endocrinology, 60, 778-784.

Trinder P., I960. Colorimetric micro-determination of calcium in serum. Analyst, 85, 889-94.

TyLER C., I954. Studies on egg shells. IV. The site of deposition of radio-active calcium and phosphorus. J. Sci. Food Agric., 5, 335-9.

Winget C. M., SMith A. H., r958. Changes in the plasma calcium concentr. ti , during egg formation. Poultry Sci., 37, 509-12.

Winget C. M., Smith A. H., Hoover G. N., I958. Arterio-venous differences in plasma calcium concentration in the shell gland of the laying hen during shell formation. Poultry Sci., 37, 5325.8 .

Wooton I. D. P., r964. Micro-analysis in medical biochemistry. London, J. and A. Churchill Ltd. p. 7I 